\title{
Immunohistochemical Localization of Cellubrevin on Secretory Granules in Pancreatic B-cells*
}

\author{
Mariko OMatsu-Kanbe ${ }^{1}$, Wei-Guang Ding ${ }^{1}$, Mitsuru Hashiramoto ${ }^{2}$ and Hiroshi Kitasato ${ }^{1}$ \\ Department of Physiology ${ }^{1}$, Shiga University of Medical Science, Otsu; and The Second Department of Internal Medicine ${ }^{2}$, Kobe \\ University School of Medicine, Kobe, Japan
}

Received May 6, 1997

Summary. Cellubrevin is one of the proteins involved in the docking and fusion of secretory granules to the plasma membrane. It has been reported that cellubrevin is widely distributed in both neural and non-neural cells, including insulin-secreting B-cells. This study aims to demonstrate by immunohistochemical techniques that cellubrevin is localized in insulin-secreting cells and further to examine whether it might occur in glucagonand somatostatin-secreting cells in the pancreatic islet in the rat and mouse. We used the polyclonal antiboby against the $\mathrm{N}$-terminal peptide whose specificity was confirmed by Western blot analysis. Double immunostaining demonstrated that cellubrevin was localized in insulin-containing cells, but both glucagon-containing and somatostatin-containing cells lacked the immunoreactivity. Immuno-electron microscopic analysis revealed the localization of cellubrevin on the margin of secretory granules near the plasma membrane but not in the granules closer to the nucleus. These observations support the view that cellubrevin in the pancreatic islet is expressed on the membrane of the secretory granules in B-cells at the stage of exocytosis.

A considerable number of studies have recently been carried out on the characterization of the proteins responsible for vesicle docking and fusion processes of cytoplasmic granules and vesicles. These include the N-ethylmaleimide-sensitive factor (NSF), soluble $\mathrm{NSF}$-attachment proteins (SNAPs), vesicle associated membrane proteins (VAMPs, also known as synaptobrevins) for SNAPs receptors in vesicles, and SNAP-25 and syntaxins for SNAPs receptors in the plasma membrane (TRIMBLE et al., 1988; ELFERINK et al., 1989; ARCHER III et al., 1990; WILSON et al., 1992; BENNETT et al., 1993; HATA et al., 1993; HoRIKAWA et al., 1993). Moreover, SöLLNER et al. (1993) have hypothesized that vesicles interact with their target membranes via the binding of SNAP receptors on vesicles and target membranes. Involvement of a direct and specific interaction between VAMPs and syntaxins has been demonstrated in synaptic vesicle transmission in neurons (CALAKOS et al., 1994). Some non-neural cells, such as adipocytes (TAMORI et al., 1996; Timmers et al., 1996; ChEATHAM et al., 1996), muscles (RALSTON et al., 1994) and parotid acinar cells (FuJITA-YoshIGAKI et al., 1996), have also been reported to express VAMPs (synaptobrevins).

Cellubrevin is one of the most recently discovered members of the VAMP family. Although it has been hypothesized that this protein is involved in membrane fusion mechanism in eukaryotic cells, its distribution among neural and non-neural cells has reportedly been diverse and controversial. Very few studies on the immunohistochemical localization of cellubrevin are available. In the RNA and immuno blot investigation, MCMAHON et al. (1993) even claimed that cellubrevin is distributed ubiquitously among cells. It has also been reported to be localized not only in supportive cells in the brain (glial, endothelial and ependymal cells) but also expressed together with VAMP-1 and 2 in other cells which have exocytosis and vesicular trafficking systems such as PC12 cells (CHILCOTE et al., 1995), 3T3-LI adipocytes (TAMORI et al., 1996; ChEATHAM et al., 1996; MARTin et al., 1996), adipose cells (Timmers et al., 1996), and insulin-secreting cell lines (REGAZZI et al., 1996).

It has been reported that VAMPs (synaptobrevins) and their related proteins are expressed in insulinsecreting B-cells of the pancreas (BAUMERT et al.,

\footnotetext{
*This study was supported by a Grant-in-Aid for Science, Research on Priority Area of "Channel-Transporter Correlation" (07276102) from the Japanese Ministry of Education, Science and Culture.
} 
1989; JACOBSSON et al., 1994; REGAZZI et al., 1995) and insulinoma cell lines (BoYD et al., 1995). More recently, REGAZZI et al. (1996) have shown that VAMP-2 and cellubrevin play a role in $\mathrm{Ca}^{2+}$-dependent insulin secretion. The precise assignment of each VAMP isoform in contributing to insulin secretion is still unclear.

In order to determine whether cellubrevin is localized only in insulin secreting cells or generally expressed in endocrine cells in the pancreas, we investigated the immunohistochemical localization of cellubrevin in the rat and mouse pancreas. We further investigate the fine-structural localization of cellubrevin in the B-cell in correlation with the view that this protein is involved in the exocytotic mechanism of secretory granules.

\section{MATERIALS AND METHODS}

Male ICR mice aged 7 to 10 weeks and male SpragueDawley rats $(180-250 \mathrm{~g})$ were used.

\section{Antibodies}

The peptide corresponding in sequence to residues 113 of the rat cellubrevin (MCMAHON et al., 1993) was coupled to keyhole limpet hemocyanin. The conjugate $(1.5 \mathrm{mg})$ was emulsified with complete Freud's adjuvant and injected into New Zealand white rabbits. Rabbit antibody production was boosted by injection of the antigen emulsified in complete Freud's adjuvant. The obtained immune serum was subjected to experiments as an anti-cellubrevin antibody. Anti-human insulin monoclonal antibody was purchased from Nippon Bio-Test Lab, Inc. (Tokyo, Japan), and anti-rat glucagon polyclonal antibody was obtained from Immuno Nuclear Corp. (USA). Anti-rat somatostatin monoclonal antibody (BUCHAN et al., 1985) was generously supplied from MRC Regulatory Peptide Group (University of British Columbia, Canada).

The antibody specificity used here was examined by Western blot analysis. The rats were deeply anaesthetized and killed by decapitation. The pancreas was removed immediately after sacrifice, minced into pieces and digested with collagenase. Isolated islets were picked up by pipette under a microscope. The tesis was removed and minced into pieces. Isolated islets and minced testis were homogenized in $200 \mathrm{mM}$ sucrose, $1 \mathrm{mM}$ EDTA and $10 \mathrm{mM}$ Tris- $\mathrm{HCl}$, $\mathrm{pH} 7.4$, containing $10 \mu \mathrm{g} / \mathrm{ml}$ leupeptin and $400 \mu \mathrm{M}$ PMSF and centrifuged at $12,000 \mathrm{~g}$ for $10 \mathrm{~min}$ to remove the debris. Membrane fractions were pelleted from the resulting supernatant by centrifugation at
$100,000 \mathrm{~g}$ for $20 \mathrm{~min}$. SDS-PAGE was performed by the method by LAEMMLI (1970). Proteins resolved by SDS-PAGE were electrophoretically transferred to the poly(vinylidene difluoride)-membrane, and the membrane was incubated with anti-cellubrevin antibody $(1: 500)$. Immunoreactive proteins were detected using alkaline phosphatase-labeled anti-rabbit IgG ( $1: 5,000$; Sigma, USA) and visualized with a reaction mixture of nitroblue tetrazolium $(0.33 \mathrm{mg} / \mathrm{ml}$; GIBCO BRL. USA) and 5-bromo-4-chloro-3-indolyl-phosphatase $(0.165 \mathrm{mg} / \mathrm{ml}$; GIBCO BRL, USA) dissolved in $0.1 \mathrm{M}$ Tris- $\mathrm{HCl}$ containing $0.1 \mathrm{M} \mathrm{NaCl}$ and $50 \mathrm{mM} \mathrm{MgCl}_{2}$ (pH 9.5).

\section{Immunohistochemistry}

The animals were deeply anaesthetized with nembutal prior to sacrifice and perfused via the left cardiac ventricle with $0.01 \mathrm{M}$ phosphate-buffered saline ( $\mathrm{pH} 7.4)$, followed by an ice-cold fixative containing $4 \%$ paraformaldehyde. $0.2 \%$ picric acid and $0.35 \%$ glutaraldehyde in $0.1 \mathrm{M}$ phosphate buffer ( $\mathrm{pH}$ 7.4). After perfusion, the pancreas was removed and immersed for 2 days in a fixative containing $4 \%$ paraformaldehyde and $0.2 \%$ picric acid in $0.1 \mathrm{M}$ phosphate buffer $\left(\mathrm{pH} \mathrm{7.4)}\right.$ at $4^{\circ} \mathrm{C}$. The samples were then placed for an additional 4 days in 15\% sucrose in $0.1 \mathrm{M}$ phosphate buffer $(\mathrm{pH} 7.4)$ at $4^{\circ} \mathrm{C}$ and cryo-cut into thin sections $(20 \mu \mathrm{m})$. The cryo-sections were incubated with anti-cellubrevin antiserum $(1: 3,000)$, treated with biotinylated sheep anti-rabbit IgG (Vector Lab. Inc., USA), and visualized using an avidin-biotin-peroxidase complex (Vector Lab. Inc.), and $3.3^{\prime}$-diaminobenzidine-nickel reaction system.

\section{Double immunofluorescence staining}

Immunostaining of simultaneous or sequential double immunostaining of single sections was used. In simultaneous double immunostaining, the cryo-sections were incubated with anti-cellubrevin polyclonal antiserum $(1: 3,000)$ and an anti-insulin monoclonal antibody $(1: 10,000)$ or anti-somatostatin monoclonal antibody $(1: 2,000)$. They were then stained with both FITC-labeled anti-rabbit IgG $(1: 100)$ and rhodaminelabeled anti-mouse IgG $(1: 100)$. After staining with these fluorescent labels, the sections were examined under a confocal laser micorscope (MRC 600, Bio Rad, England; DIAPHOT 300, Nikon, Japan). In the sequential double immunostaining by TRAMU et al. (1978), the cryo-sections were first immunostained for cellubrevin and FITC-labeled anti-rabbit IgG and examined, and then treated with acid potassium permanganate to remove the antibodies. The completeness of the antibody removal was tested by application of FITC-labeled anti-rabbit IgG. Only 
sections devoid of immunofluorescence were futher processed for the immunocytochemical demonstration of glucagon. The sections were then incubated with anti-glucagon antiserum $(1: 3,000)$ and stained with FITC-labeled anti-rabbit IgG $(1: 100)$. The same areas of the sections which had been previously analyzed under the confocal laser microscope were then examined.

\section{Immunoelectron microscopy}

Thin sections were immunostained with anti-cellubrevin antiserum using the method described above. Following the $3,3^{\prime}$-diaminobenzidine reaction, stained sections were postfixed for one hr with $1 \% \mathrm{OsO}_{4}$ in $0.1 \mathrm{M}$ phosphate buffer $(\mathrm{pH} 7.4)$ at $4^{\circ} \mathrm{C}$. They were dehydrated in ethanol and embedded in Epon according to conventional procedures. Ultrathin sections were examined under an electron microscope (HS-9, Hitachi, Japan) after a brief staining with uranyl acetate and lead citrate. Control experiments were performed to examine the ultrathin sections without uranium-lead staining (data not shown). The uranium-lead staining had no effect on the dense materials prestained with $3,3^{\prime}$-diaminobenzidine.

\section{RESULTS}

Results of Western blot analysis in membrane fractions of the rat pancreatic islets probed with cellubrevin antiserum are shown in Figure 1. For the ubiquitous distribution of cellubrevin expression, we used the testis as a positive control (MCMAHON et al., 1993; MARTIN et al., 1996). The antiserum against cellubrevin revealed a single band of $\sim 17 \mathrm{kDa}$, corresponding to the known molecular size of cellubrevin. As shown in Figure 1, the antiserum preincubated with the corresponding antigenic peptide gave no positive band in Western blot staining. These observations indicate the validity and specificity of the antibody used in immunohistochemical studies of pancreatic islet cells.

Immunostaining of cellubrevin in the mouse and rat pancreas is shown in Figure 2. Immunoreactive cellubrevin is mainly present in the islets of Langerhans but not in the exocrine tissue surrounding the islets. The evidence that the absorption of the antiserum with its antigenic peptide $(50 \mu \mathrm{g} / \mathrm{ml})$ completely abolished the immunostaining in the islets of Langerhans, and the negative staining using non-immune rabbit serum (data not shown) further support the specificity of this antiserum.

In order to examine the distribution of cellubrevin

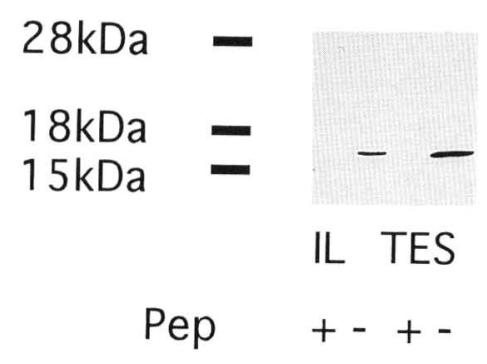

Fig. 1. Western blot analysis probed with anti-cellubrevin antiserum. Membrane proteins (50 $\mu \mathrm{g}$ each) were subjected to Western blot with an anti-cellubrevin antibody in the presence and absence of an antigenic peptide. Pep: $10^{-4} \mathrm{M}$ antigenic peptide, IL: pancreatic islets, TES: testis.
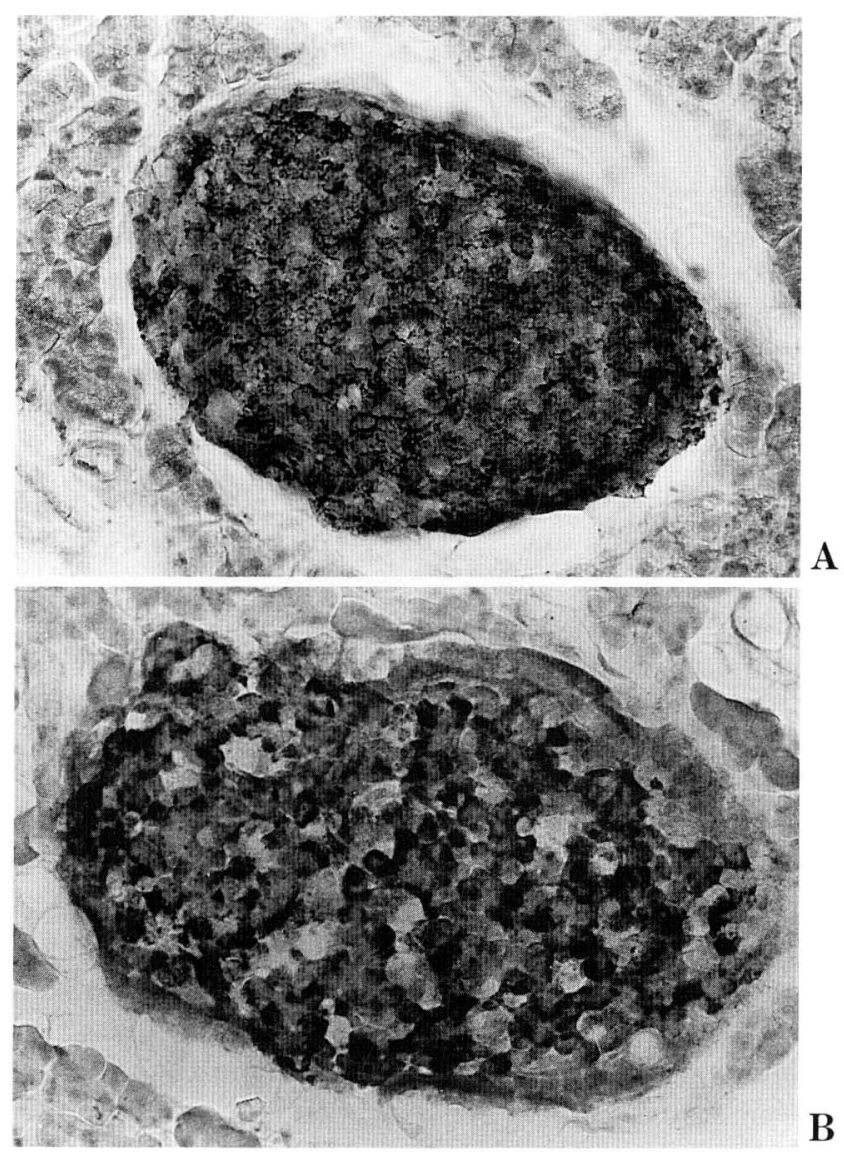

Fig. 2. Immunoreaction for cellubrevin in mouse (A) and rat (B) pancreatic islets. $\times 280$ 

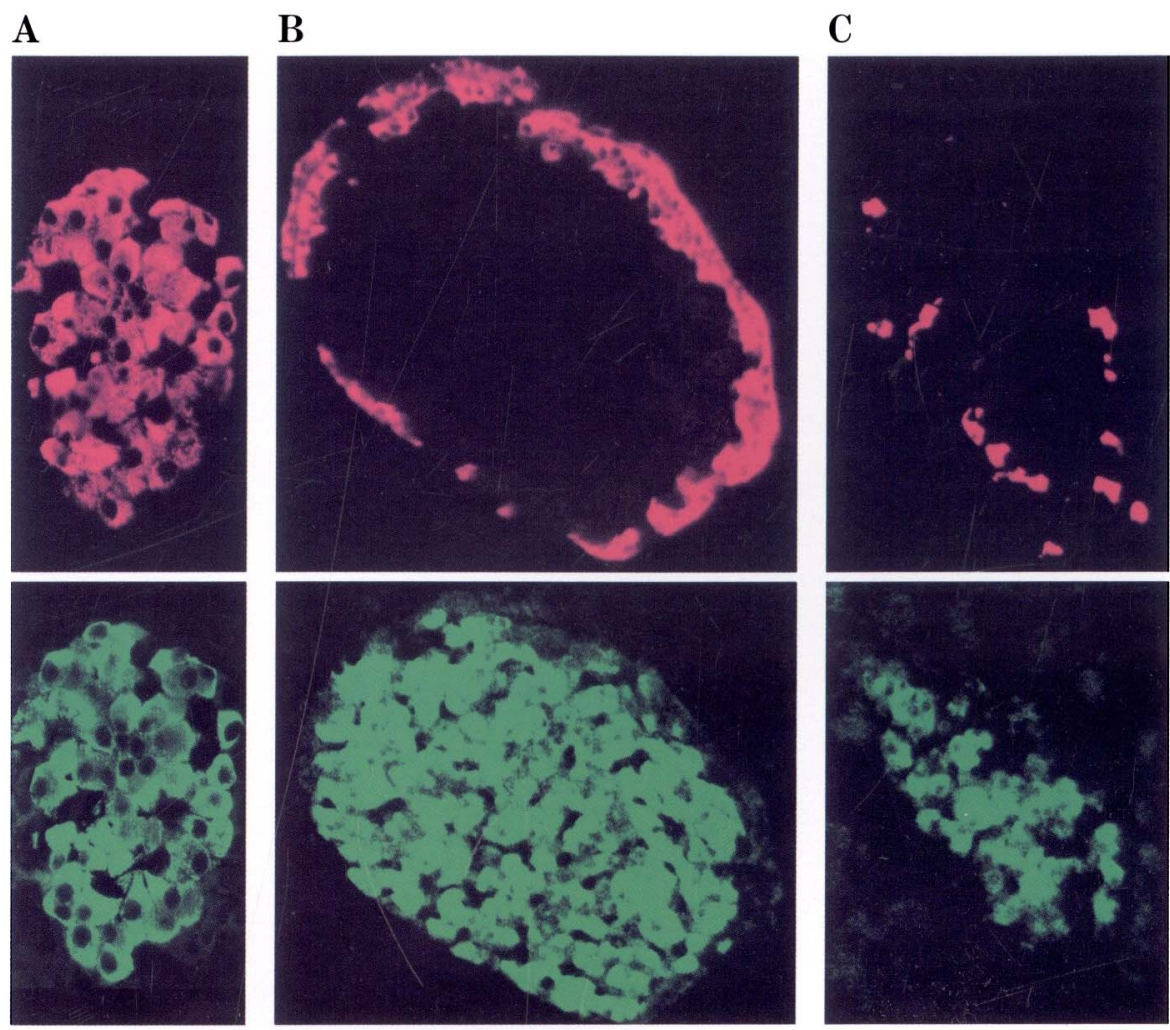

$\mathbf{B}^{\prime}$

$\mathbf{C}^{\prime}$

Fig. 3. Double immunofluorescence staining for cellubrevin and one of the islet hormones: insulin, glucagon and somatostatin. Rat pancreatic islets. Cryo-sections were double-stained for insulin (A), glucagon (B) or somatostatin (C), and for cellubrevin $\left(\mathbf{A}^{\prime}, \mathbf{B}^{\prime}, \mathbf{C}^{\prime}\right)$, and treated with rhodamine- or FITC-labeled anti-mouse or antirabbit IgG. The sections were examined under a confocal laser microscope. $\times 100$. For further details, see Materials and Methods.

in the islets, double labeling experiments using anticellubrevin antiserum and anti-insulin monoclonal antibody were performed. Figure $3 \mathrm{~A}$ shows a pancreatic islet containing a large number of cells reactive to anti-insulin antibody. Cellubrevin was detected in the anti-insulin antibody reactive cells, considered to be B-cells (Fig. 3A'). We further attempted in this study to ascertain if cellubrevin is localized in other endocrine cells in the pancreatic islet, A-cells and D-cells. Figure 3B shows that cells reactive to antiglucagon, considered to be A-cells, are located along peripheral sites of the islet. Cellubrevin was localized in the core of the islet and not in the glucagonimmunoreactive cells (Fig. 3B'). Figure 3C further shows that cells reactive to the anti-somatostatin antibody, considered to be D-cells, are located in the periphery of the islet, and that the localization of cellubrevin does not correspond to these cells (Fig. $\left.3 C^{\prime}\right)$.
To identify the localization of cellubrevin within pancreatic B-cells, we conducted an immunoelectron microscopic analysis. As indicated in Figure 4A, the secretory granules containing electron dense materials, which approach the plasma membrane, are stained with anti-cellubrevin antibody, but those located near the nucleus are not reactive to anticellubrevin antibody. Close association of these granules with the plasma membrane in areas adjacent to the wall of the capillaries suggests a secretory role for the granules with immunostained cellubrevin (Fig. 4B). Immunodeposits indicating cellubrevin were also associated with plasma membrane regions, near which the capillary endothelium could often be seen (Fig. 4B, arrowheads). This may be also thought to be the area of the very early stage of endocytosis. 


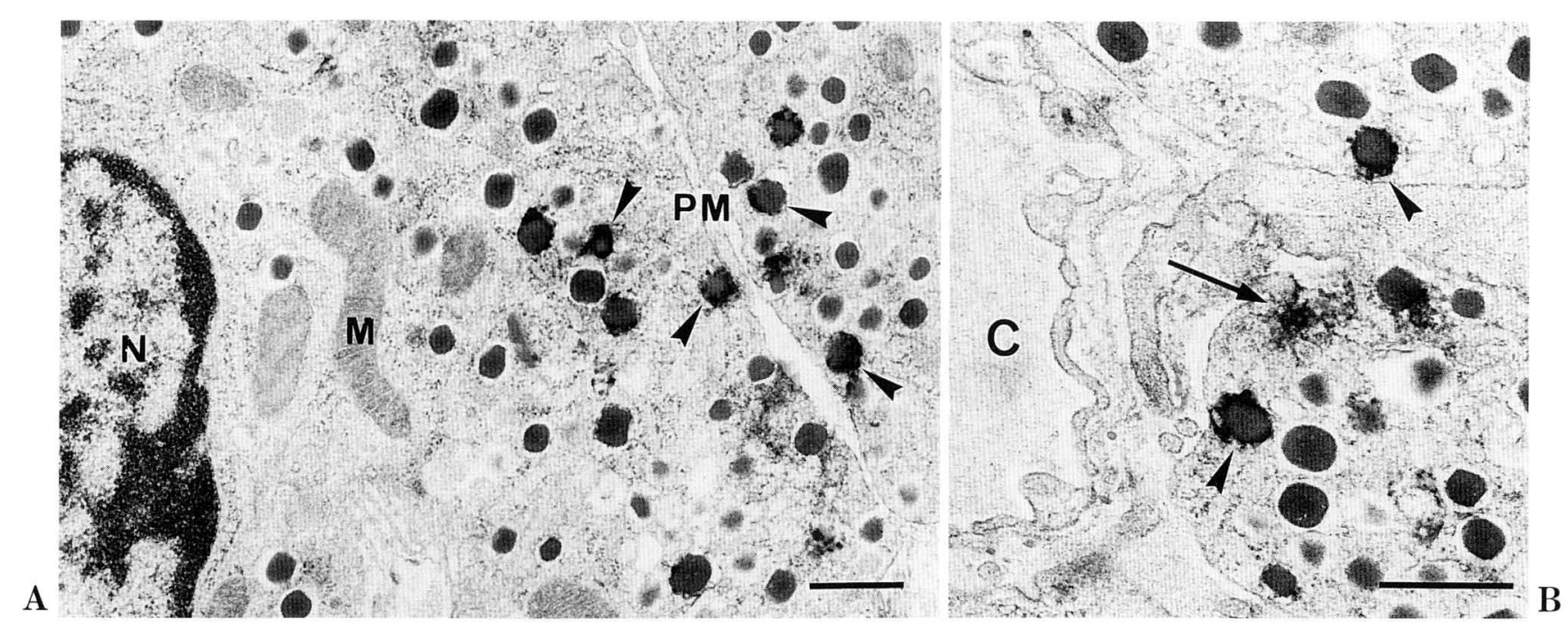

Fig. 4. Immunoelectron microscopic detection of cellubrevin on secretory vesicles in mouse pancreatic B-cells. A shows electron-dense material indicating immunolabeled cellubrevin located on the margin of secretory granules near the plasma memcrane. B shows immunolabeled cell portions facing a blood capillary wall. Note that only granules close to the plasma membrane and to the capillary are immunolabeled for cellubrevin. $N$ nucleus, $M$ mitochondria, $P M$ plasma membrane, $C$ capillary. Arrowheads indicate immunostained cellubrevin; arrow indicates a possible exocytotic granule which is hit rather tangentially and is immunostained with cellubrevin. Bar: $0.5 \mu \mathrm{m}$.

\section{DISCUSSION}

Several studies on the localization of VAMPs (synaptobrevins) in the pancreas have been reported previously. BRAUn et al. (1994) concluded that endocrine islets contain primarily VAMP-2, and that exocrine cells express primarily VAMP-1 or another VAMP isoform in their apical side. JACOBSSON et al. (1994) have shown mRNA of VAMP-2 and cellubrevin in the isolated pancreatic islet by in situ hybridization. REGAZZI et al. (1995) have confirmed that VAMP-2 and cellubrevin are found in subcellular fractions of both insulin-containing and sinaptic-like granules, and, using confocal laser microscopic analysis, that VAMP-2 is associated with insulin-containing granules. Originally, cellubrevin was thought to be involved in constitutive exocytosis according to the study on RNA and immunoblot analysis (MCMAHON et al., 1993). Recent reports have demonstrated that cellubrevin and VAMP-1 and 2 possess a similar function concerned with regulated vesicular trafficking in PC12 cells (CHILCOTE et al., 1995) and adipocytes (TAMORI et al., 1996; Timmers et al., 1996; CheATHAM et al., 1996).

A large number of studies concerned with the mechanism of ion channels and insulin secretion have been conducted (reviewed by RAJAN et al., 1990;
Atwater et al., 1994). However, the molecular mechanism of exocytosis has not been fully investigated. Cellubrevin is the most recently discovered member of the family of VAMPs (synaptobrevins) and is also a substrate for tetanus and botulinum neurotoxins (LINK et al., 1993; MCMAHON et al., 1993; GALLI et al., 1994; YAMASAKI et al., 1994). In addition to a report that tetanus and botulinum toxin block neurotransmitter release (SCHIAvo et al., 1993), it has been shown that the cleavage of cellubrevin by these neurotoxins impairs exocytosis of transferrin receptor-containing vesicles (GALLI et al., 1994) and the translocation of glucose transporter (GLUT4)-containing vesicles in various types of cells (TAMORI et al., 1996; Timmers et al., 1996; Cheatham et al., 1996). In insulin-secreting cells, it has also been reported that $\mathrm{Ca}^{2+}$-dependent insulin secretion essentially requires VAMP-2 and cellubrevin (BOYD et al., 1995; REGAZZI et al., 1995, 1996).

In the present study, we investigated the immunolocalization of cellubrevin in the pancreatic islet using a polyclonal anti-cellubrevin antibody. It is noteworthy that cellubrevin was detected only in B-cells, but not in A-cells or in D-cells (Fig. 3). These observations support the view that cellubrevin plays an essential role in insulin secretion (BOYD et al., 1995; REGAZZI et al., 1995, 1996). It is possible that VAMP-2 may be involved in both insulin secretion in 
B-cells, glucagon secretion in A-cells, and somatostatin secretion in D-cells.

The immunoelectron microscopic study showed that the secretory granules located near the plasma membrane were stained with the anti-cellubrevin antibody, but those located near the nucleus were not reactive to the anti-cellubrevin antibody (Fig. 4). These observations suggest that cellubrevin is not distributed on all the secretory granules equally within the B-cell, but develops or concentrates on the membrane of the secretory granules in the late stage of exocytosis. There is some possibility that the expression of cellubrevin in the pancreatic B-cells is related to the maturation process of the secretory granules.

This is the first report to show immunohistochemical identification of cellubrevin on secretory granules in pancreatic B-cells. The difference between the function of cellubrevin and VAMP-2 in insulin-secreting pancreatic B-cells, and the relationship between these proteins and electrophysiological activities in pancreatic B-cells will be the focus of a future study.

Acknowledgements. We thank Mr. Takefumi YAmAмото (Central Research Laboratory, Shiga University of Medical Science) for assisting in the use of the confocal laser microscope. We also thank Prof. H. KImURA (Institute of Molecular Neurobiology, Shiga University of Medical Science) for generously providing facilities for use during research for this study.

\section{REFERENCES}

ARChER III, B. T., T. ÖZceliK, R. JAhN, U. Francke and T. C. SÜDHOF: Structures and chromosomal localizations of two human genes encoding synaptobrevins 1 and 2. J. Biol. Chem. 265: 17267-17273 (1990).

Atwater, I., M. Kunuljan and E. M. Pérez-Armendarinz: Molecular biology of the ion channels in the pancreatic $\beta$-cell. In: (ed. by) B. DrazNin and D. LeRoITH: Molecular biology and diabetes. Humana Press, Totowa, NJ, 1994 (p. 303-332).

Baumert, M., P. R. Maycox , F. Navone, P. DeCamilli and R. JAHN: Synaptobrevin: an integral membrane protein of 18000 daltons present in small synaptic vesicles of rat brain. EMBO J. 8: 379-384 (1989).

BENNETt, M. K., J. E. GarCía-ArRarấs, L. A. ElfFerink, K. Peterson, A. M. Fleming, C. D. Hazuka and R. H. SchELLER: The synataxin family of vesicular transport receptors. Cell 74: 863-873 (1993).

Boyd, R. S., M. J. Duggan, C. C. Shone and K. A. Foster: The effect of botulinum neurotoxins on the release of insulin from the insulinoma cell lines HIT-15 and RINm5F. J. Biol. Chem. 270: 18216-18218 (1995).
Braun, J. E. A., B. A. Fritz, S. M. E. Wong and A. W. LowE: Identification of a vesicle-associated membrane protein (VAMP)-like membrane protein in zymogen granules of the rat exocrine pancreas. J. Biol. Chem. 269: 5328-5335 (1994).

Buchan, A. M. J., L. K. J. SiKoRA, J. G. Levy, C. H. S. McIntosh, I. Dick and J. C. Brown: An immunocytochemical investigation with monoclonal antibodies to somatostatin. Histochemistry 83: 175-180 (1985).

Calakos, N., M. K. Bennett, K. E. Peterson and R. H. SCHELLER: Protein-protein interactions contributing to the specificity of intracellular vesicular trafficking. Science 263: 1146-1149 (1994).

Cheatham, B., A. Volchuk, C. R. Kahn, L. Wang, C. J. RHODES and A. KLIP: Insulin-stimulated translocation of GLUT4 glucose transporters requires SNAREcomplex proteins. Proc. Nat. Acad. Sci. USA 93: 1516915173 (1996).

Chilcote, T. J., T. Galli, O. Mundigl, L. Edelmann, P. S. McPherson, K. Takei and P. De Camilli: Cellubrevin and synaptobrevins: Similar subcellular localization and biochemical properties in PC12 cells. J. Cell Biol. 129: 219-231 (1995).

Elferink, L. A., W. S. Trimble and R. H. Scheller: Two vesicle-associated membrane protein genes are differentially expressed in the rat central nervous system. J. Biol. Chem. 264: 11061-11064 (1989).

Fujita-Yoshigaki, J., Y. Dohke, M. Hara-Yokoyama, Y. Kamata, S. Kozaki, S. Furuyama and H. Sugiya: Vesicle-associated membrane protein 2 is essential for cAMP-regulated exocytosis in rat parotid acinar cells. J. Biol. Chem. 271: 13130-13134 (1996).

Galli, T., T. Chilcote, O. Mundigl, T. Binz, H. Niemann and P. De Camilli: Tetanus toxin-mediated cleavage of cellubrevin impairs exocytosis of transferrin receptor-containing vesicles in CHO cells. J. Cell Biol. 125: 1015-1024 (1994).

Hata, Y., C. A. Slaughter and T. C. Südhof: Synaptic vesicle fusion complex contains unc-18 homologue bound to syntaxin. Nature (Lond.) 366: 347-351 (1993).

Horikawa, H. P. M., H. Saisu, T. Ishizuka, Y. Sekine, A. Tsugita, S. Odani and T. Abe: A complex of rab3A, SNAP-25, VAMPs/synaptobrevin-2 and syntaxins in brain presynaptic terminals. FEBS Lett. 330: 236-240 (1993).

Jacobsson, G., A. J. Bean, R. H. Scheller, L. JunttiBerggren, J. T. Deeney, P.-O. Berggren and B. MEISTER: Identification of synaptic proteins and their isoform mRNAs in compartments of pancreatic endocrine cells. Proc. Nat. Acad. Sci. USA 91: 12847-12491 (1994).

LAEMmLI, U. K.: Cleavage of structural proteins during the assembly of the head of bacteriophage $\mathrm{T}_{4}$. Nature (Lond. ) 227: 680-685 (1970).

Link, E., H. McMahon, G. F. Von Mollard, S. YaMASAKI, H. NiemanN, T. C. SüDHOF and R. JahN: Cleavage of cellubrevin by tetanus toxin does not affect fusion of early endosomes. J. Biol. Chem. 268: 1842318426 (1993). 
Martin, S., J. Tellam, J. W. Slot, G. W. Gould and D. E. James: The glucose transporter (GLUT-4) and vesicle-associated membrane protein-2 (VAMP-2) are segregated from recycling endosomes in insulin-sensitive cells. J. Cell Biol. 134: 625-635 (1996).

McMahon, H. T., Y. A. Ushiaryov, L. Edelmann, E. Link, T. Binz, H. NiemanN, R. JAHN and T. C. SüDHOF: Cellubrevin is a ubiquitous tetanus-toxin substrate homologous to a putative synaptic vesicle fusion protein. Nature (Lond.) 364: 346-349 (1993).

Rajan, A. S., L. Aguilar-Bryan, D. A. Nelson, G. C. YANeY, W. H. Hsu, D. L. Kunze and A. E. BoYd III: Ion channels and insulin secretion. Diabetes Care 13: 340-363 (1990).

Ralston, E., S. Beushausen and T. Ploug: Expression of the synaptic vesicle proteins VAMPs/synaptobrevins 1 and 2 in non-neural tissues. J. Biol. Chem. 269: 1540315496 (1994).

Regazzi, R., C. B. Wolheim, J. Lang, J.-M. Theler, O. Rossetto, C. Montecucco, K. Sadoul, U. Weller, M. Palmar and B. Thorens: VAMP-2 and cellubrevin are expressed in pancreatic $\beta$-cells and are essential for $\mathrm{Ca}^{2+}$ - but not for GTPS-induced insulin secretion. EMBO J. 14: 2723-2730 (1995).

Regazzi, R., K. Sadoul, P. Meda, P. B. Kelly, P. A. HAlban and C. B. Wollheim: Mutational analysis of VAMP domains implicated in $\mathrm{Ca}^{2+}$-induced insulin exocytosis. ENMO J. 15: 6951-6959 (1996).

Schiavo, G., F. Benfenati, B. Poulain, O. Rossetto, P. P. De Laureto, B. R. Dasgupta and C. Montecucco: Tetanus and botulinum-B neurotoxins block neurotransmitter release by proteolytic cleavage of synaptobrevin. Nature (Lond.) 359: 832-835 (1992).

Söllner, T., S. W. Whiteheart, M. Brunner, H. Erdjument-Bromage, S. Geromanos, P. Tempst and J. E. Rothman : SNAP receptors implicated in vesicle targeting and fusion. Nature (Lond.) 362: 318-324 (1993).

Tamori, Y., M. Hashiramoto, M., S. Araki, Y. Kamata, M. Takahoshi, S. Kozaki and M. Kasuga: Cleavage of vesicle-associated membrane protein (VAMP)-2 and cellubrevin on GLUT4-containing vesicles inhibits the translocation of GLUT4 in 3T3-L1 adipocytes. Biochem. Biophys. Commun. 220: 740-745 (1996).
Timmers, K. I., A. E. Clark, M. Omatsu-Kanbe, S. W. Whiteheart, M. K. BennetT, G. D. Holman and S. W. Cushman: Identification of SNAP receptors in rat adipose cell membrane fractions and in SNARE complexes co-immunoprecipitated with epitope-tagged $\mathrm{N}$ ethylmaleimide-sensitive fusion protein. Biochem. J. 320: 429-436 (1996).

Tramu, G., A. Pillez and J. Leonardelli: An efficient method of antibody elution for the successive or simultaneous localization of two antigens by immunocytochemistry. J. Histochem. Cytochem. 26: 322-324 (1978).

Trimble, W. S., D. M. Cowan and R. H. Scheller: VAMP-1: a vesicle-associated integral membrane protein. Proc. Nat. Acad. Sci. USA 85: 4538-4542 (1988).

Wilson, D. W., S. W. Whiteheart, M. Widemann, M. BrunNer and J. E. Rothman: A multisubunit particle implicated in membrane fusion. J. Cell Biol. 117: 531538 (1992).

Yamasaki, S., A. Baumeister, J. Blasi, E. Link, F. Cornille, B. Roques, E. M. Fykse, T. C. Südhof, R. JAHN, H. NiEMANN and T. BINZ: Cleavage of members of the synaptobrevin/VAMP family by types D and F botulinal neurotoxins and tetanus toxin. J. Boil. Chem. 269: 12764-12772 (1994).

Dr. Mariko Omatsu-KanBE Department of Physiology Shiga University of Medical Science Otsu, 520-21 Japan

尾松 万里子 520-21 大津市瀬田月輪町 滋賀医科大学 生理学第二講座 